\title{
The Significance of names in the fiction of Elie Wiesel
}

\author{
Simon P. Sibelman \\ University of Wisconsin, Oshkosh
}

The onomastic element of a story whether recounted within an oral or 1 a written tradition conventionally serves a vital role. Names possess powerful magical, historical and metaphorical powers which when combined with other aspects of the tale establish a significant communicative fil conducteur. Names traditionally echo events crucial to the history and culture of a family, a tribe or a people, resounding with primary and secondary memories of former triumphs and tragedies. Moreover, with the ascendancy of the novel as the dominant literary genre in occidental, bourgeois culture, names - both first and surnames - exercise considerable symbolic weight in plot evolution and character development, as well as defining a character's particular social category. Yves Reuter has crystallized this importance by stating: "Ainsi le nom désigne les personnages, les inscrit dans l'univers social et le système des oppositions du roman, condense des informations et symbolise les acteurs"(149).

In his collection of essays, Modernity on Endless Trial, Leszek Kolakowski notes that: "ever since objects, actions and attributes were named by Adam, reality, which thus far had been perceptible without words, could not remain the same"(34). Kolakowski is, I believe, not merely highlighting the profound effect that words and language exert upon our perceptions of reality, but he hints as well at the centrality of 
names and the essential links they provide between man and creation. "Au commencement, l'homme ne s'orientait que par rapport à Dieu - et toute la Création se définissait par rapport à l'homme" (Célébration, 15). Elie Wiesel firmly establishes humanity's pivotal position in the spectrum of creation and its relation to the Creator. But, for Man to serve as such a point de référence, he required a name by which he might be addressed as well as communicate with the Creator, Creation and other human beings.

In his extensive auvre, Wiesel has repeatedly stressed the general contextual prominence of names both in reality and in literature. He senses that many people in our post-Auschwitz world conveniently ignore the significance of names. In a consumer-oriented, "disposable" society where television has become a substitute for life, why should individuals expend energy in serious considerations of the choice of a name ${ }^{1}$ Rather than recognizing the fundamental existential link between the name and the human being, Wiesel's perspective suggests that people have come to choose names frivolously or serendipitously. After all, should a name be deemed unpleasing or unfashionable, one does have the legal option to alter it. And yet, I strongly believe along with Wiesel that names are far too consequential to be cast off as casually as plastic bottles or outdated appliances. ${ }^{2}$

The Wieselian universe has been consciously and staunchly constructed upon the vital link between characters and their names. "Il y a quelque chose d'éternel, d'immortel dans chaque nom" (Wiesel, Portes 24). ${ }^{3}$ Wiesel fully exploits this particular notion in his fiction, where the vast majority of his protagonists' names are constructed upon the Hebrew morpheme -EL ( ${ }(\mathcal{K})$, one of the principal biblical appellations for God. Thus, he not only establishes that vital relationship between the Almighty and Mankind, but likewise imbues his protagonists with an element of immortality, a divine 'spark' which will metaphorically propel them into life-affirming acts and into a recognition of the omnipresence of the Divine in this world. "En créant l'homme, Dieu lui fit don du secret, non du commencement, mais du recommencement" (Célébration 35, emphasis added). 
Despite his use of the signifier $-E L$, one can nevertheless detect a profound dis-ease among certain Wieselian protagonists who continually appear to wrestle with the Divine element in their names. This struggle, itself a critical leitmotif in much of Wiesel's fiction, produces somewhat contradictory onomastic connotations as the designated names themselves frequently manifest astoundingly opposing meanings. Consider the following example. The name of the protagonist in Wiesel's fourth novel, La Ville de la chance (The Town Beyond the Wall), Michael, obviously possess the aforementioned Hebrew morpheme, $-\boldsymbol{E L}$. A cursory analysis of this Hebrew name would render an English meaning of "Who is like unto thee, $\mathrm{O}$ Lord," a positive paean of praise suggesting the power of the deity and metonymically implying that this potency has been or will be mystically transferred to the protagonist as the result of some initiatory rite of passage. Yet, based upon an extended talmudic exegesis proposed by Emmanuel Levinas, this same name can render another translation: "God is weak/impoverished," based upon the Hebrew rootword mah (D), signifying being feeble, poor or demonstrating weakness (123) . This blatant, oxymoronic onomastic conflict highlights the motifs of struggle and confusion which abound in the text. Moreover, such a fundamental contradiction expressed from within the linguistic interiority of the name itself emphasizes, in a broader sense, the incongruity between the notion of a loving and just God and the reality of evil in the world, an idea most often represented in Wiesel's fiction by the Holocaust and its aftermath.

A similar onomastic paradox manifests itself in Wiesel's novel Le Testament d'un poète juif assassiné (The Testament). Paltiel, the protagonist's name, can be interpreted as "God is my refuge" equally as well as "I am a refugee from God." Wiesel clearly reflects this dichotomy in Paltiel's painful struggle to conclude his existential exile and perhaps to reconcile himself with his own authentic identity, a quest which eventually results in his seeking refuge in the fundamental essence of his own sublimated Jewishness. Ironically, as Paltiel achieves at-one-ment, the two discrepant senses of his name are conciliated and a tenuous state of harmony attained.

The antithesis of this particular device occurs in those Wieselian texts where principal characters remain purposefully unnamed. If the act of 
naming signifies an affirmation of life through the introduction of a divine element into the world, and if it similarly represents an attempt at the establishment of crucial, communicative links, then a lack of naming is a metonymic approximation for death and emphasizes the absence of any fecund dialogal relationships. Wiesel only rarely proposes such situations, their having surfaced in only three novels: Le Jour (The Accident), Le Serment de Kolvillàg (The Oath), Le Cinquième fils (The Fifth Son). These novels represent intense metaphysical struggles between life and death, the unnamed characters challenged to choose life replete with its imperfections rather than remaining in their death-like state.

A number of mysterious and rather mystical characters likewise populate the Wieselian literary universe, their names frequently possessing catalytic powers facilitating dédoublement and thus effecting wholeness or resurrection. Gavriel/Grégor in Les Portes de la forêt and David/Katriel in Le Mendiant de Jérusalem form two such doubled pairs, one the metaphorical alter ego of the other. Moreover, their names complement one another. In the first text, for example, the protagonist opts to abandon his Hebrew name, Gavriel and its powerful meanings of "strength" or "hero of God," conferring it upon a nameless stranger. In turn, he assumes the Greek Christian name, Grégor, itself signifying "vigilant" or "watchman." Though seemingly an act of Sartrian lâcheté, Wiesel's literary strategy thereby elicits a specific scenario the leitmotif of which evokes a fundamental struggle within the protagonist himself in order to be re-named Gavriel. For that to occur, Grégor must be enlightened and strengthened through a host of encounters, including one with himself when he must wrestle with his past and his present in order to secure psychic wholeness. Only then can he again become one with his former name and the positive sense it propounds. Similarly, in the second novel, David, the "beloved one" and eponymous name sake of the biblical king of Israel and his dynasty from which will arise the Messiah, remains an uncrowned monarch in search of the mystical Katriel, "God's Crown," who alone can assist David in reintroducing God into Creation . In both cases, one depends upon the other. Together these pairs establish productive, symbiotic relationships representing a whole 
spiritual being and resulting in some degree of metaphysical transformation and transcendence.

In the aforementioned examples, one again discerns Wiesel's continued use of the -EL morpheme in constructing the names of these fictional characters. The names of several other characters do, however, deviate from this pattern. Twice, in La Ville de la chance (The Town Beyond the Wall) and again in Le Crépuscule, au loin (Twilight), Wiesel introduces Pedro, an enigmatic persona whose existence even within the text's structural parameters is dubious. This Spanish appellation might appear somewhat incongruous in the predominantly Hebraic onomastic inventory established here. And yet, this name does indeed propound profound significance in the respective texts. I would propose that Wiesel has employed this name, which means "the Rock," in order to suggest another of the Biblical names of God, Tzur ( $(Y)$ ) or "Rock." This ludic echoing is not coincidental but rather illustrates direct authorial intention, as Tzur in its Biblical antecedents signifies communication and dialogue. In those texts where this character surfaces, Pedro is responsible for drawing the protagonist into substantial, dialogal links with humanity, and for standing as the texts' principal catalytic power ensuring renewal and the positive ontological evolution of other characters. For example, the lessons the protagonist has learned as Pedro's disciple lead him to save the life of a fellow prisoner, Menachem, and later to attempt to have 'the Silent One,' another prisoner in a catatonic state, speak of his own past.

Another curious incursion of an apparently non-Hebraic name occurs in Wiesel's novel, Le Jour. Gyula, described as "peintre d'origine hongroise. . grand, robuste. . il bousculait tout sur son passage" (290), represents a primary regenerative force that draws the nameless protagonist back toward life. Given the aforementioned authorial characterization of Gyula, the name would seem to suggest a Magyar source. I would, however, propose that the name, while outwardly

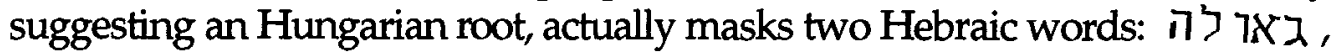
meaning salvation or redemption; גיל ג , signifying joy or rejoicing. The name's non-Hebraic appearance belies a more profound significance, a Hebraic sense that conveys the essence of the character's motivations 
and actions. It is Gyula who effectively redeems the protagonist, restoring a sense of hope and future joy should he choose to live.

This sort of authorial onomastic ludus arises again in Le Cinquième fils (The Fifth Son) where Wiesel introduces the non-Hebraic name: Paritus-leBorgne. In this instance, I believe a more thorough analysis will provide clearer insights into Wiesel's scrupulous application of names in his fiction.

Initially appearing as a fleeting reference early in the text, the character, if indeed he might be so labelled, silently insinuates himself into the core of the novel, exerting a constant and deliberate influence upon one of the protagonists, Reuven Tamiroff. And yet, Paritus-le-Borgne does not seem to occupy an active place in the novel's plot as an active, developed character. According to Tamiroff, who has engaged upon an obsessive task of compiling information about him, his favorite author, Paritus is a philosopher "dont les Méditations obliques ont influencé la pensée religieuse, et antireligieuse" (Le Cinquième fils, 20). ${ }^{4}$ One can infer from Tamiroff's remarks that as Paritus is ranked as a notable philosophical voice, one ought to be able to discover traces of his thought or his life in some general reference text. But, in reality, the name of this notable philosopher receives no mention in any source about religion or philosophy. Wiesel presents an enigmatic figure whose real existence remains highly suspect; and, within the parameters of the text,the character's actual literary function appears questionable. Given Wiesel's careful attention to the onomastic elements in his novels, one must consequently query what possible purpose Paritus serves. Thus, in order to establish some degree of enlightenment as to Wiesel's intention in introducing so mysterious a character into this novel, one ought to engage upon a similar methodological search as with the other names: an etymological analysis. The results of such a search offer riveting clues as to the precise identity of Paritus.

The name, Paritus, suggests a Latin base. The closest root form is paro which generates several other constructs such as parito and pario. The root paro and its most closely related form parito mean "to prepare," "to get ready," "to be about to do a thing." Given the novel's plot, it is obvious 
that Reuven is preparing something through his research, though the outcome and meaning are not divulged. We, like Reuven's unnamed son, are trapped in a silent void of ignorance. This onomasiological investigation similarly notes that the Latin pario means "to bring forth (as children)." More interestingly, this form not only has etymological links with paro, but also with the Hebrew verb parah ( 179 ), "to bear fruit," a morpheme which in Hebrew can likewise refer to having children. Moreover, another Latin verb, parere, offers the word paritum, meaning "the one who obeys his master" or "the one who conforms," connotations which might even suggest an interpretation of "one who blindly obeys."

In the full name of the mysterious fictional philosopher, Paritus-leBorgne, the determining 'le-Borgne' indicates the loss of an eye or the obstruction of vision. Considering the various significations which the present etymological search has provided - notably the link between the Latin pario and the Hebrew parah - I would propose here that Reuven Tamiroff emerges as Paritus-le-Borgne. If, as I believe, the name, Paritus, has been employed by Wiesel as a synonym for 'father,' the sobriquet $l e-$ Borgne refers to Reuven's loss of sight of the real world in which he lives. His obsessive sentiments of guilt have driven him into a silent universe which distorts the reality around him. His research, therefore, concerns himself and his guilt-ridden relationship to the mysterious 'cinquième fils,' his first-born son, Ariel, who had died during the Holocaust. Reuven's vision has become oblique, his energies channelled into letters written to that dead son. Moreover, I would advance the proposition that in those letters lie the origins of Paritus's Méditations obliques, a notion that receives additional, substantive support when the narrator - the unnamed son - wanting to read his father's work on Paritus, discovers these letters in his father's notebooks. "Ces lettres, où les as-tu trouvées ?" his father asks. "Par hasard. Un jour j'ai voulu lire ton manuscrit sur Paritus. Elles étaient cachées à l'intérieur" $(C F, 165)$. The significance of this finding will be treated later. For the moment, however, one can observe in this incident the degree to which Reuven (Paritus) has been blinded (le-Borgne) to his parental responsibilities to his living son, a boy 
who becomes a nameless entity in the face of the wall of silence erected by his father.

In his book Un Survivant, Moshè Garbarz confided to his son: "L'heritage [ $d$ ' Auschwitz] était intransmissible," yet together with his son he sets down his testimony of la vie quotidienne in the anus mundi (7). Though the difficulty of transmitting that nearly ineffable experience presses Moshè Garbarz toward silence, he recognizes his urgent and unique responsibility to speak as a survivor and especially as a parent. Speaking becomes a particular mode of survival. In his study of Beckett's works, Ludovic Janvier stresses a similar point:

Raconter pour survivre, revenir à soi guéri d'illusion, repartir vers les autres par le pouvoir des mots, glisser lentement vers le centre: $c^{\prime}$ est dans ce va-et-vient, dans cette évolution que s'exécute l'immobile et secret travail qui emprunte, pour se faire, le secours du voyage par d'autres êtres. C'est dire que la parole vit de l'autre, que le personnage veut un frère, qu'il est le lieu d'un couple (6869) .

It is precisely this logic that Reuven Tamiroff rejects. Reuven, whose name means "behold, a son!" negates the fundamental essence of his appointed identity. He refuses to speak, abdicating his responsibilities as a parent and as a human being, and merely stagnates in silent contemplations of himself (viz., Paritus-le-Borgne) and of the horrors of his past. Within a Wieselian context, Man must attempt above all else to establish dialogue with his fellow beings. True human contact is vital and assists the individual in an attachment to life. Moreover, within the framework of parental responsibilities, dialogal contact aids the evolution of a child's character and identity. Thus, I would suggest that the mystical powers inherent in names would, in the context of this novel, appear to have been abrogated. Consider the following.

Reuven's determination to remain silent confuses his son. Mysteries are evoked which have no apparent solution. Even when Reuven's friends attempt to bridge the gap between father and son, past and present, they 
are aware that certain secrets can only be divulged by Reuven himself. His son struggles to comprehend those things his father ought to tell him but which have remained silenced. The son's failure to force his father to speak and thus enable him to uncover some degree of truth leads to a sense of mounting frustration and anger.

Tu te dis bon juif ... tu te crois mon père mais le devoir $d u$ père n'est-il pas de transmettre son savoir, son expérience à son fils? Or, ne suis-je pas ton fils, ton fils unique? Quel père es-tu donc si tu t'obstines à vivre emmuré $(C F, 134)$.

The narrator finally forces his father to speak when he announces the chance discovery of his father's considerations on Paritus's Méditations obliques, which are nothing more than Reuven's tragic, guilt-ridden correspondence with the dead 'fifth son,' Ariel. The effect of Reuven's 'research' stuns his son, implanting within him seeds of guilt for merely having been born:

J'écoute mon père et j'ai l'impression d'entendre un conte irréel, merveilleux. Les paroles coulent et se fondent les unes dans les autres.... Je comprends beaucoup de choses désormais, mais j'ignore si ce sera source de douleur ou de paix. La solitude de mon père et celle, plus visible, plus concrète de ma mère malade; tous deux vivent avec leur enfant mort; ils cherchent en moi leur fils disparu, mon frère Ariel $(C F, 168)$.

The nameless narrator views himself as the cause of the malefic silences that have dominated the home and driven his mother into catatonic madness. In his estimation, his existence is the reason for all the suffering he has witnessed.

Reuven's silences seem to have stemmed from his own guilt at having 'brought forth,' parah, Ariel, during the war and having been unable to preserve that precious life. These guilty silences ironically and selfishly rise out of his psyche to deform his living son's identity. The anonymous son suffers inordinately for he has been obliged to formulate questions that might offer some responses in the face of his father's silence. The 
youth desperately examines himself not to uncover his own silenced identity but to probe the mysteries shrouding Paritus-le-Borgne and thus, perhaps, to understand his father. Moreover, Reuven's silences and the enigma of his alter ego hold the key to unlocking his son's identity. The boy becomes entangled in this complex web of searching for an identity that comprises three souls: Reuven, Ariel and the nameless narrator himself. The narrator vainly seeks to fuse the three into one. His guilt at having usurped his brother's position in his father's life further complicates his own natural development. Confused and distracted, the narrator urgently seeks to construct bridges between himself, his father, and his dead brother. He feels compelled to don the mantle that is Paritus. His links, like those of his father, will consist of words forming new meditations: the narrator's own letters to his dead brother, Ariel.

Durant septembre, j'écris beaucoup. Plus qu'avant, plus que jamais. Pour me détendre? Pour comprendre. Pour me réconcilier avec mon père, je marche sur ses traces: j'écris des lettres à Ariel. Si lui peut écrire à son fils disparu, moi, je peux bien écrire à mon frère unique, à mon frère mort $(C F, 176)$.

Through his own letters and meditations, the narrator gradually assumes the identity of his dead brother. This somewhat lugubrious act of dédoublement, in which the moi mort and the moi survivant are projected together, momentarily provides the anonymous son a name. Robert Jay Lifton believes that "doubling is an active psychological process, a means of adaptation to extremity," an adaptation which requires the dissolving of the 'psychic glue' which had assured the solidity of the original self (422). In Wiesel's novel, the nameless narrator, as a result of his father's silences, has never been a stable psychological self. Thus, when faced with the trauma of truth, the original self, which has deemed itself guilty and even destructive, rapidly adopts the identity of the dead brother. And, as the 'fifth son,' as Ariel ("the Lion of God"), he similarly assumes the responsibility to achieve a single goal: the death of $l^{\prime}$ Ange, the Nazi 'Angel of Death,' otherwise known to be the SS commander who had liquidated the ghetto of Davarowsk and had consequently been responsible for Ariel's death. In his quest for an identity, which had led 
him to this dédoublement, the narrator has desperately chosen to accomplish that which his father had attempted and failed to do after the war. The 'sons' of Reuven Tamiroff link together and hope to avenge the past and perhaps thereby exorcise the ghosts that possess and silence Reuven. Their bizarre union likewise symbolizes the realization that the Jewish God of justice and life has temporarily been replaced by a 'Nazi' god of death. Yet even this act of dédoublement cannot destroy l'Ange, the very essence of the banality of evil. The narrator's fragmented, ambiguous, doubled identity fails as absolutely as had Reuven after the war.

The novel's conclusion, which remains highly enigmatic, reveals that the events narrated in the course of the story were not contemporary but had occurred ten and twenty years previously. The narrator continues: "Les temps ont changé. Et moi? Moi- qui?" (CF, 227). Despite the passage of time and the events that had occurred, the crisis of identity has not been resolved:

Aujourd'hui encore j'entretiens des rapports passionnels et ambigus avec mon nom. Ariel Tamiroff désigne un autre que moi.... Graduellement, j'avais observé en moi un dédoublement d'être; Ariel était et n'était pas mort; moi, j'étais et je n'étais pas vivant (CF, 227).

The protagonist remains anonymous, fragmented, hovering between life and death. He would like to comprehend all that has befallen, but a foreboding ignorance sadly shrouds him: "Ce que je désire comprendre, jamais on ne me l'expliquera" (CF, 229). This, in part, represents the heritage of Paritus-le-Borgne. The narrator does, however, advance one curious notion, namely that of his relationship with his father. "Certes, nous avons eu nos différends, nos querelles, nos conflits; mais les distances se sont muées en liens renouvelés" $(C F, 230)$. How was this transition achieved? Were these new links established when Reuven broke his silence in order to reveal the identity of the 'fifth son'; or, did they evolve after the narrator's attempt to avenge Ariel's death? The responses to these and other questions remain hidden in the silences and ambiguities which abound in the text. Or perhaps, for the moment, our inability to respond clearly to such mysteries indicates a pressing need for the arrival of the Messiah who will resolve all insoluble problems, an attitude clearly 
articulated by the anonymous narrator: "Le Messie risque d'arriver trop tard. .. . Tant pis: j'attendrai tout de même" $(C F, 229)$. Meanwhile, in the silent interim between the present and the Messiah's advent, one can merely pose questions, for as the Passover Haggadah says of the youngest son who does not know how to ask, every individual has the moral obligation to teach him to do so. ${ }^{5}$

In Le Cinquième fils, Wiesel has considered the painful process of having one's identity plunged into the abyss of silence, for that is the significance imparted by Paritus-le-Borgne, his name and his meditations. And yet, emerging from that message, Wiesel's novel demonstrates the abiding belief in the importance of dialogal relationships between parents and children, a vital component in establishing any legitimate image of oneself. Moreover, for Wiesel, the establishment of genuine Jewish identity projects that individual into living and entails a moral responsibility to preserve and protect life, and one's identity. Speaking of authentic Jewish existence, Wiesel says:

Cela signifie que nous vivons malgré la Mort, que nous survivons à la Mort! Cela signifie que notre histoire ... est un défi permanent à la raison et au fanatisme, aux bourreaux et à leur puissance! $(C F, 38)$

This novel proposes the notion of a challenge; it demonstrates how many must frequently struggle and, if need be, rebel against those forces that would destroy or silence aspects of one's true nature. Wiesel's image of the Jew is as an 'Every Man,' a being who suffers for whatever reasons and eventually must defend his or her rights and beliefs as well as those of other individuals. Each person must participate in life, become a living part of history, encountering and struggling with the essence hidden in each name. It is only in that manner that the truth of history can be safeguarded from menacing silence and that positive silence can be given its proper place within history. That represents the abiding legacy and significance hidden within the mystery of Partitus-le-Borgne.

One characteristic of the author whose works survive throughout the years is the keen regard given to the significance of the names of the 
characters. Choosing particular onomastic elements for any work of fiction represents an critical extension of an author's selection of other aspects of the lexical inventory. Names form a sort of signature to the story, communicating meaningful connotations that help to describe the character and reflect central complications in the plot. Elie Wiesel's choice of names illustrates meticulous authorical attention to detail and correspondingly highlight the rich spiritual life his characters possess. More importantly, in the chaotic post-Auschwitz world, Wiesel's application of names stresses the re-introduction of the divine element in the human dimension, the restoration of significant dialogue and the re-establishment of communion and an awareness of being whole and of being part of a greater whole: the human family.

\section{Notes}

'Similar attitudes towards names were evoked in a letter written by Franz Rosenzweig on 21 August 1917 when he stated: "One thing is certain, I have no real feeling about my first name. I can only guess why this is so. It may be because my parents gave it to me without any particular feeling, simply because they 'liked it.' And why did they like it? - because at that time it was 'different.' It's as though my parents had seen it in a shop window, walked inside and bought it. It has nothing traditional about it, no memory, no history, not even an anecdote, scarcely a whim it was simply a passing fancy" (Colodner, 5).

${ }^{2} \mathrm{C} f$. my arguments concerning the importance of names and the struggle to retrieve a discarded name in the context of Wiesel's novel Les Portes de la forett in "The Dialogue of Peniel: Elie Wiesel's Les Portes de la forêt and Genesis 32:2333," The French Review 61:5 (April 1988): 745-757.

${ }^{3} \mathrm{Cf}$. Wiesel's remarks in "Entretien," La Tribune juive (Paris), 192 (May 1972): 17.

${ }^{4}$ All pages references to this novel $(C F)$ will appear in parentheses in the text.

${ }^{5}$ The Passover Festival commences with a ritual meal, the Seder, which follows a particular order set down in a book, the Haggadah. This book, whose title literally means "to tell a tale," recounts the Israelite's liberation from slavery in Egypt and the spiritual and physical formation of the Jewish people. 


\section{Works Cited}

Colodner, Solomon, editor. What's Your Name? (A Dictionary of Names). Ramat Gan, Israel: Cole Publications, 1981.

Garbarz, Moshè and Elie. Un Survivant. Paris: Plon, 1984.

Janvier, Ludovic. Pour Samuel Beckett. Paris: Les Editions de Minuit, 1966.

Kolakowski, Lesek. Modernity on Endless Trial. Chicago: The University of Chicago Press, 1990.

Levinas, Emmanuel. Quatre lectures talmudiques. Paris: Les Editions de Minuit, 1968. Lifton, Robert Jay. The Nazi Doctors: Medical Killing and the Psychology of Genocide. New York: Basic Books, 1986.

Reuter, Yves. Introduction à l'analyse du roman. Paris: Bordas, 1991.

Wiesel, Elie. Célébration biblique: Portraits et légendes. Paris: Les Editions du Seuil, 1975. . Le Cinquième fils. Paris: Bernard Grasset, 1983. . La Nuit, L'Aube, Le Jour. Paris: Les Editions du Seuil, 1969. . Les Portes de la foret. Paris: Les Editions du Seuil, 1964. 